\section{Flowering Behavior and Pollination Requirements in Climbing Cacti with Fruit Crop Potential}

\author{
Julia Weiss ${ }^{1}$, Avinoam Nerd ${ }^{2}$, and Yosef Mizrahi ${ }^{1,2}$ \\ Ben-Gurion University of the Negev, P.O.Box 1025, Beer Sheva 84110, Israel
}

Additional index words. Hylocereus, Selenicereus megalanthus, pitaya, compatibility system, fruit set, seeds, pollen viability

\begin{abstract}
The reproductive biology of the climbing cacti Hylocereus polyrhizus (Weber) Britt. \& Rose, H. undatus (Haworth) Britt. \& Rose, H. costaricensis (Weber) Britt. \& Rose, and Selenicereus megalanthus (Schum. ex Vaupel) Moran (syn. Mediocactus megalanthus) was studied with the aim of cultivating the cacti in Israel as fruit crops. Flowering in Hylocereus spp. occurred in two to three waves during the summer, whereas in $S$. megalanthus, flowering was concentrated at the end of autumn. Flowers of all species opened 1 to 1.5 hours before sunset and closed $\approx 6$ hours after sunrise. In the Hylocereus spp., $\boldsymbol{H}$. polyrhizus and $\boldsymbol{H}$. costaricensis were self-unfruitful, and cross-pollination with other species led to high fruit set $(\mathbf{1 0 0 \%})$. Hylocereus undatus was self-fruitful, setting fruit with self-pollen. Cross-pollination between the clones of $S$. megalanthus led to a high fruit set and each clone was self-fruitful. In contrast to $H$. undatus, $S$. megalanthus clones could set fruit without pollen vector involvement, although the set was slightly lower than with hand pollination. Pollen source influenced fruit weight. In the self-fruitful species of Hylocereus, fruit obtained by hand cross-pollination with other Hylocereus spp. were significantly heavier than fruit obtained by hand self-pollination. The largest fruit in each of the Hylocereus spp. were obtained by specific cross-combinations within the group. Fruit of S. megalanthus had a lower weight than fruit of the Hylocereus spp. Flowers of all species were visited by day-active honeybees only. Fruit set and fruit weight with open pollination was lower than with hand pollination in Hylocereus spp. Since stigma receptivity and pollen germinability stayed high during anthesis, the low pollination effectivity has to be related to other factors, such as the short bee visits and the absence of specific adaptation by the bees to the flower. In S. megalanthus, fruit set and fruit weight with open pollination were similar to values obtained with hand pollination. This similarity is probably related to the fact that pollen transfer in open pollination is achieved by bee visits and direct transfer of pollen to the stigma, which occurs via physical contact between anthers and stigma during flower closing.
\end{abstract}

Climbing epiphytic cacti, members of the genera Hylocereus and Selenicereus, are found throughout Central America, the West Indies, and western Mexico (Britton and Rose, 1963). These cacti are branched climbers that attach their slender stems to trees or rocks via adventitious roots, which grow along the stems. These roots also serve to absorb water (Gibson and Nobel, 1986).

Several species of Hylocereus and Selenicereus, known as strawberry pear (Morton, 1987), produce medium to large fruit, traditionally consumed by the local population (Cacioppo, 1990). In Latin America, the plants and their fruit are known as pitaya or pitahaya (Donají Ortiz Hernandez, 1993). The Hylocereus fruit are characterized by a red peel with large scales and a white or red pulp, while those of Selenicereus have a knobby yellow peel with spines and a white flesh (Britton and Rose, 1963; Kimnach, 1984;

Received for publication 9 Mar. 1994. Accepted for publication 18 Aug. 1994. The cost of publishing this paper was defrayed in part by the payment of page charges. Under postal regulations, this paper therefore must be hereby marked advertisement solely to indicate this fact.

${ }^{1}$ Department of Life Sciences.

${ }^{2}$ The Institutes for Applied Research. (Morton, 1987). Cultivation of selected spe-

Fig. 1. Flower of Hylocereus polyrhizus. cies has begun recently, $H$. undatus in Nicaragua and Vietnam and S. megalanthus in Colombia (Barbeau, 1990; Cacioppo, 1990).

Studies are rare on the reproductive biology of the climbing cacti. The flowers are hermaphroditic, nocturnal, and strongly scented. Each flower is large, up to $30 \mathrm{~cm}$ long, with a long flower tube that fans out into a funnel-shaped corolla with thin, white petals (Fig. 1). A nectary chamber is located at the bottom of the flower tube (Britton and Rose, 1963). Flowers exhibit characteristics of those pollinated by night-active bats and large hawkmoths (Grant and Grant, 1979; Haber, 1983). Three species, H. ocamponis, H. undatus, and $S$. megalanthus, are probably autogamous and the visits of pollinators increase fruit set (Cacioppo, 1990; Cullmann et al., 1987; Kimnach, 1967).

Preliminary studies in Israel show that climbing cacti are susceptible to high solar irradiation and become bleached when grown in the open; however, plants develop well and flower when they are shaded (Raveh et al., 1993). In their studies, flowers did not set fruit, suggesting fertilization failure, possibly due to a lack of pollen vector activity, or to compatibility problems. The objective of the present study was to examine flowering behavior and pollination requirements in selected species of Hylocereus and in S. megalanthus, with the aim of proposing agromanagements that will enable them to be grown commercially.

\section{Materials and Methods}

Plant material and study site. Clones of four species were examined (Table1). For two of them, H. undatus and S. megalanthus, two genotypes in each one, differing in origin and morphological traits, produced abundant flowers during the study period. The investigation was therefore extended to two clones within these species. Cuttings for propagation were obtained from the Huntington Botanical Garden in California, from a private garden in

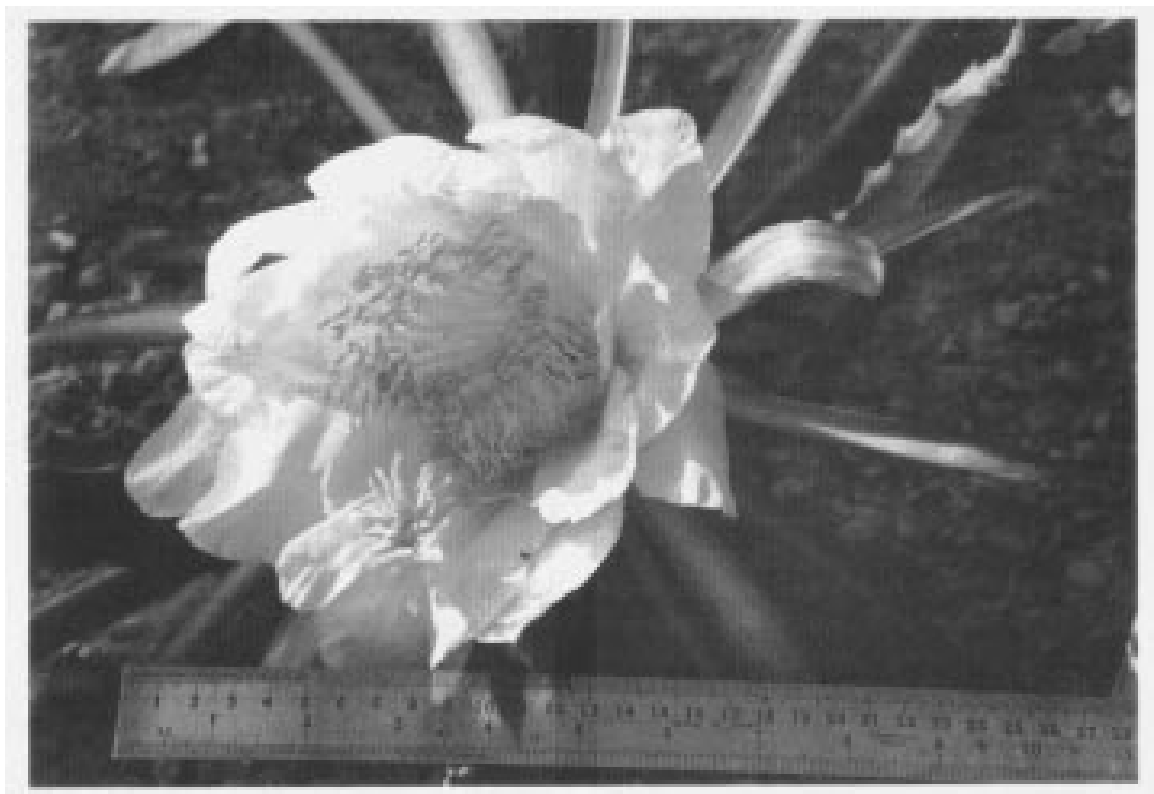


Table 1. Plant material, fruit characteristics, and source for climbing cacti.

\begin{tabular}{|c|c|c|c|}
\hline Species & $\begin{array}{l}\text { Local clone } \\
\text { designation }\end{array}$ & Fruit characteristics & Source \\
\hline \multicolumn{4}{|l|}{ Hylocereus polyrhizus (Weber) } \\
\hline Britton \& Rose & & $\begin{array}{l}\text { Fruit oblong; peel dark-red with } \\
\text { large scales; pulp violet-red }\end{array}$ & $\begin{array}{l}\text { Huntington Botanical Garden, Calif., } \\
\text { collection no. } 15885 \text { HBG }\end{array}$ \\
\hline \multicolumn{4}{|l|}{ H. undatus (Haworth) } \\
\hline \multirow[t]{2}{*}{ Britton \& Rose } & A & $\begin{array}{l}\text { Fruit oblong; peel light-red with } \\
\text { large scales; pulp white }\end{array}$ & Private garden, Israel \\
\hline & B & $\begin{array}{l}\text { Fruit oblong; peel light-red with } \\
\text { large scales; pulp white }\end{array}$ & Private garden, Israel \\
\hline \multicolumn{4}{|l|}{ H. costaricensis (Weber) } \\
\hline Britton \& Rose & & $\begin{array}{l}\text { Fruit round; peel dark-red with } \\
\text { large scales; pulp violet-red }\end{array}$ & $\begin{array}{l}\text { Huntington Botanical Garden, Calif., } \\
\text { collection no. } 49639 \text { HBG }\end{array}$ \\
\hline \multicolumn{4}{|l|}{ Selenicereus megalanthus } \\
\hline (Schum. ex Vaupel) Moran & A & $\begin{array}{l}\text { Fruit oblong; peel yellow with } \\
\text { tubercles and spines; pulp white }\end{array}$ & Plantation, Colombia \\
\hline Syn. Mediocactus megalanthus & B & $\begin{array}{l}\text { Fruit oblong; peel yellow with } \\
\text { tubercles and spines; pulp white }\end{array}$ & Wild, Ecuador \\
\hline
\end{tabular}

Israel, from commercial plantations in Colombia, and from the wild in Ecuador. The study was carried out in 1992 and 1993 in Beer Sheva, which is situated in the northern Negev Desert of Israel. The experiments were performed on 3- to 4-year-old plants in greenhouses under $50 \%$ shade, which were covered with polyethylene during the coldest months (November to March). Six plants of each clone were grown in two greenhouses. The cuttings were planted in sandy soil at a spacing of 1.5 $\times 1.5 \mathrm{~m}$, and a trellis system $1.5 \mathrm{~m}$ in height was installed for supporting the plants. Water containing $20 \mathrm{~N}-20 \mathrm{P}-20 \mathrm{~K}$ fertilizer was applied by dripper at a concentration of each 70 ppm N $\left(\mathrm{NH}_{3} \mathrm{NO}_{3}+\mathrm{KNO}_{3}\right), \mathrm{P}_{2} \mathrm{O}_{5}\left(\mathrm{H}_{3} \mathrm{PO}_{4}\right)$, and $\mathrm{K}_{2} \mathrm{O}\left(\mathrm{KNO}_{3}\right)$ every 2 days at a weekly amount of 5 liters/plant during the hot season (May to October) and 3 liters/plant per week during the cold, wet season. At the beginning of the study, a honeybee hive was placed inside one of the greenhouses. The greenhouse was open on two sides to allow other insects to enter. The average minimum/maximum temperatures in the coldest month (January) were 18/22C and in the hottest month (August) $16 / 35 \mathrm{C}$ in both greenhouses.

Phenology of flowering, flower behavior, and insect visits. During the flowering season, all plants were monitored daily for new flowers. The flowers of three plants for each clone were observed for 5 days to determine the phases of anthesis. The presence of nectar was determined by probing the flowers with pasteur pipettes at half-hour intervals.

Breeding system and pollination type. Three treatments were applied: 1) Hand self-pollination-pollen from the same flower was applied to the stigma after flowers opened in the evening. To prevent open pollination, flowers were kept bagged except during hand pollination. 2) Hand cross-pollination-the stigma was enclosed in a small cloth bag in the afternoon before pollen was shed to prevent selfpollination; pollen gathered from a different concurrently flowering clone was applied the same evening. 3) Covered, undisturbed flowers-flowers were covered with bags throughout anthesis. Fruit set was recorded in all treatments, and fruit weight and seed count were determined. Full skin color change was an indicator for fruit harvest.
Pollen germinability and viability. Pollen germinability at anthesis and during the postanthesis stages was studied by sampling flowers at 12-h intervals, beginning at flower opening and ending $72 \mathrm{~h}$ later. Six flowers were sampled for each clone. A sample of $5 \mathrm{mg}$ of pollen was spread on a glass slide in a thin film of $1 \%$ agar containing $30 \%$ sucrose, $100 \mathrm{ppm}$ $\mathrm{H}_{3} \mathrm{BO}_{4}, 100 \mathrm{ppm} \mathrm{Ca}\left(\mathrm{NO}_{3}\right)_{2} \cdot 4 \mathrm{H}_{2} \mathrm{O}, 100 \mathrm{ppm}$ $\mathrm{MgSO}_{4}$, and $100 \mathrm{ppm} \mathrm{KNO}_{3}$. The slide was closed in a petri dish at $25 \mathrm{C}$ for $24 \mathrm{~h}$, after which the pollen sample was diluted with $1 \mathrm{ml}$ of $30 \%$ sucrose solution; then, germination was examined under a microscope. Grains were scored as germinated when tube length exceeded the diameter of the grain itself. Pollen viability was assessed by a fluorochromatic assay (Heslop-Harrison et al., 1984).

Effective pollination period. The time interval following anthesis during which pollination will result in a commercial crop is

defined as the effective pollination period, and it is a function of ovule longevity and the rate of pollen tube growth (Dennis, 1986). The effective pollination period was studied in two species, $H$. costaricensis and $H$. polyrhizus. Stigmas of flowers were bagged before anthesis and then cross-pollinated by hand with pollen of $H$. undatus (clone A) at flower opening (evening) and again in the morning and evening of the following days. [Previous unpublished studies have shown that $H$. undatus (clone A) was highly compatible with the two other species]. Fresh pollen gathered during the morning or evening, at which times in vitro pollen germinability was high, was used for pollination. Seven to 11 flowers were pollinated in each species at a time and fruit set and fruit weight were determined.

Effect of open pollination on fruit set and fruit weight. Two treatments were applied in 1993 to flowers on plants growing in the

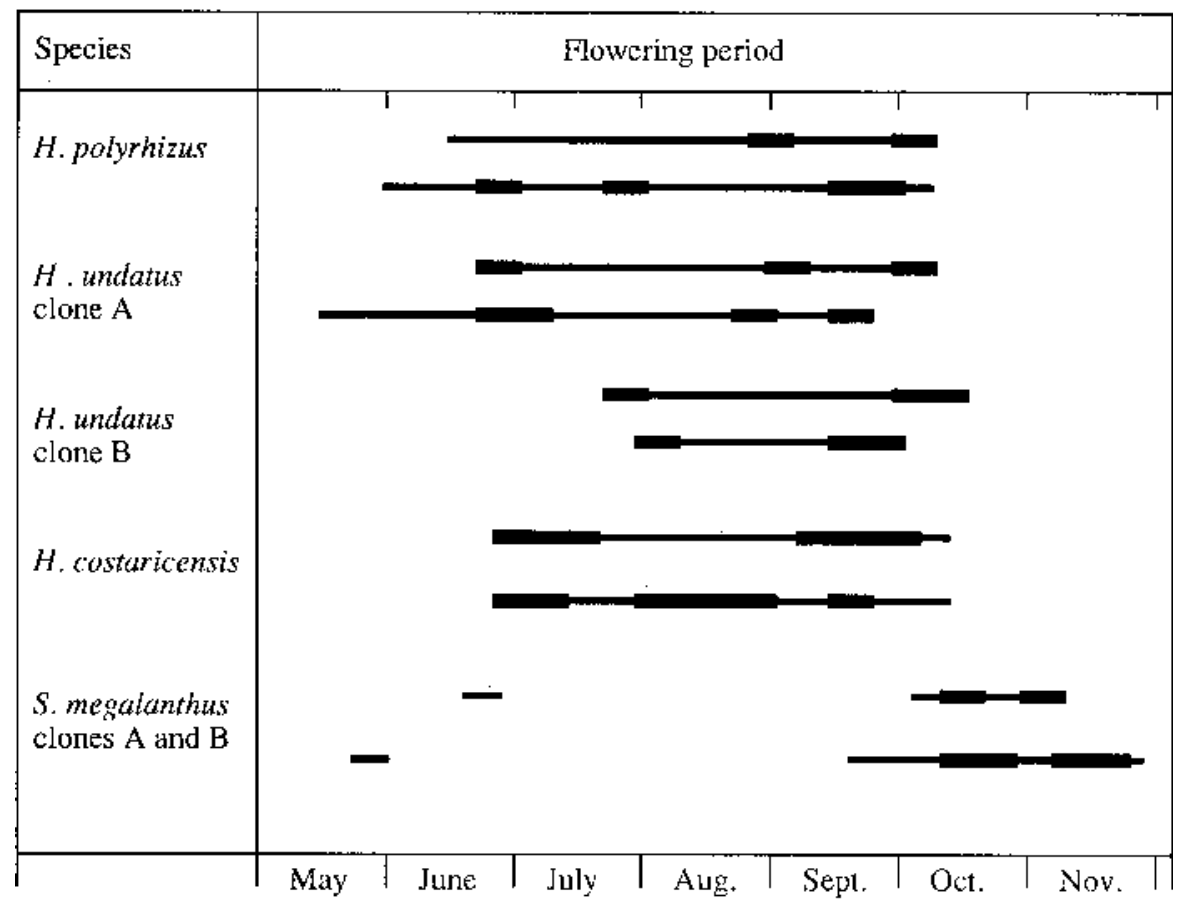

Fig. 2. Flowering periods for various species of Hylocereus and Selenicereus during the 1992-93 flowering seasons (upper line-1992, lower line-1993). The thickened sections of the lines indicate periods of concentrated flowering; at least four flowers per species were monitored each day. 
greenhouse in which the bee hive had been placed: 1) hand cross-pollination and 2) open pollination, in which flowers were exposed to insects. In all treatments, fruit set was evaluated and fruit were picked at full color change for fruit weight determination. Hylocereus spp. were studied for two consecutive years, whereas $S$. megalanthus clones were studied only in the second year due to an inadequate flower set in the first year.

\section{Results}

Flowering phenology, flower behavior, and insect visits. The number of flowers per plant averaged $9 \pm 7$ in Hylocereus spp. and $4 \pm 1$ in S. megalanthus and ranged between 5 and 25 flowers in the Hylocereus group and between 3 and 8 in S. megalanthus in the second year of the study. Flowering in the Hylocereus spp. occurred in two to three waves, mainly during summer and early autumn (May to October), whereas flowering in S. megalanthus was concentrated in autumn (October to November) (Fig. 2).

In all the species, the phases of anthesis followed a very similar pattern so that a single representative scheme is presented (Fig. 3). Flowers stayed open for one night. They began to open 1 to $1.5 \mathrm{~h}$ before sunset, were fully open by sunset, began to close $\approx 1.5 \mathrm{~h}$ after sunrise, and were fully closed by midday. Anthers dehisced 0.5 to $1 \mathrm{~h}$ before flower opening. The upper part of the anthers in the Hylocereus spp. were at least $2 \mathrm{~cm}$ below the stigma, whereas in S. megalanthus, they were at the same height as the stigma, touching it when the flowers closed. The first nectar secretion was evident when the flowers were fully open. The flowers were visited by the honeybee, Apis mellifera $\mathrm{L}$. The bees foraged for pollen and contacted the stigma frequently during their visits, which were confined to the morning, and they did not appear to reach the nectar at the base of the flower tube.

Breeding system and pollination type. Synchronization of flowering determined the type of crossing combinations (Table 2). The Hylocereus clones were crossed with each other, as were the $S$. megalanthus clones. Among the Hylocereus spp.,H. polyrhizus and $H$. costaricensis were self-unfruitful, and crosspollination with other species led to high fruit set (100\%). Hylocereus undatus was self-fruitful, setting fruit with self-pollen, but selffruitfulness was partial since a higher fruit set was obtained by cross-pollination with the other species (50\% to $80 \%$ vs. $100 \%$ ).

Cross-pollination between the $S$. megalanthus clones led to a high fruit set and each clone was self-fruitful. In contrast to $H$. undatus, they also set fruit without the involvement of a pollen vector (automatic selfpollination).

Pollen source influenced fruit weight (Table 3). In the self-fruitful species of Hylocereus, fruit obtained by hand cross-pollination with other Hylocereus spp. were significantly heavier than fruit obtained by hand self-pollination. The largest fruit in each of the Hylocereus spp. were obtained by specific

Flower open

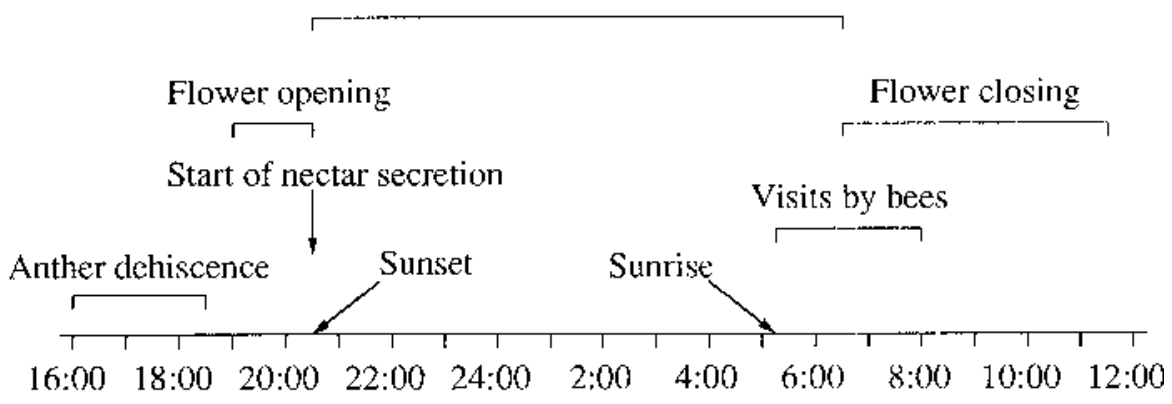

Time of the day

Fig 3. Anthesis phases and timing of insect visits to flowers in various species of Hylocereus and Selenicereus.

Table 2. Percentage of fruit set for climbing cacti in relation to the breeding system used.

\begin{tabular}{lccc}
\hline \hline & \multicolumn{3}{c}{ Fruit set (\%) } \\
\cline { 2 - 4 } Species & $\begin{array}{c}\text { Hand cross- } \\
\text { pollination }\end{array}$ & $\begin{array}{c}\text { Hand self- } \\
\text { pollination }\end{array}$ & $\begin{array}{c}\text { Covered, undisturbed } \\
\text { flowers }\end{array}$ \\
\hline Hylocereus polyrhizus & $100^{\mathrm{z}}$ & 0 & --- \\
H. costaricensis & $100^{\mathrm{z}}$ & 0 & --- \\
H. undatus clone A & $100^{\mathrm{z}}$ & 50.0 & 0 \\
H. undatus clone B & $100^{\mathrm{z}}$ & 79.6 & 0 \\
Selenicereus megalanthus clone A & $100^{\mathrm{y}}$ & 100 & 73.0 \\
S. megalanthus clone B & $100^{\mathrm{y}}$ & 100 & 60.0
\end{tabular}

alanthus clone B

${ }^{\mathrm{z}}$ Crossings with pollen from a different, concurrently flowering Hylocereus clone.

${ }^{y}$ Crossing with pollen from the other clone of $S$. megalanthus.

Table 3. Effect of pollen source on fruit weight (grams) in Hylocereus spp.

\begin{tabular}{lcccc}
\hline & \multicolumn{4}{c}{ Female } \\
\cline { 2 - 5 } Male & H. polyrhizus & $\begin{array}{c}\text { H. undatus } \\
\text { clone A }\end{array}$ & $\begin{array}{c}\text { H. undatus } \\
\text { clone B }\end{array}$ & H. costaricensis \\
\hline H. polyrhizus & --- & 580 & 567 & 384 \\
H. undatus clone A & 476 & 182 & 337 & 298 \\
H. undatus clone B & 410 & 287 & 301 & 329 \\
H. costaricensis & 539 & 633 & 495 & --- \\
Tukey's LsD & $0.05, \mathrm{n}=8$ & 90 & 102 & 46 \\
\hline
\end{tabular}

Table 4. Effect of pollination method on fruit weight (grams) in Selenicereus megalanthus.

\begin{tabular}{lcc}
\hline \hline Pollination method & $\begin{array}{c}\text { S. megalanthus } \\
\text { clone A }\end{array}$ & $\begin{array}{c}\text { S. megalanthus } \\
\text { clone B }\end{array}$ \\
\hline Self & 77 & 86 \\
Cross & 98 & 108 \\
Covered, undisturbed flowers & 38 & 51 \\
Tukey's LSD & $\mathrm{n}=8.05, \mathrm{n}=8$ & 50 \\
\hline
\end{tabular}

cross-combinations within the group.

Fruit of $S$. megalanthus weighed less than fruit of the Hylocereus spp. (Table 4). Hand cross-pollination and hand self-pollination in S. megalanthus produced fruit with similar fruit weights, which were about twice that with automatic self-pollination.

Regression analysis showed that the seed count per fruit explained $75 \%$ to $91 \%$ of the variability in fruit weight (Fig. 4). Seed count was much higher in fruit of the Hylocereus group than in those of $S$. megalanthus: maximum values ranged between 3918 and 6505 in the Hylocereus vs. 26 and 446 in $S$. megalanthus. Ovules were counted in two species: H. undatus (clone A) with many seeds and $S$. megalanthus (clone A) with relatively few. The average number of ovules was 7184 \pm 613 and $1969 \pm 176$, respectively.

Pollen germinability and viability. Pollen germinability in all species was highest when flowers started to open (Fig. 5). In $H$. polyrhizus, a sharp decline was recorded the next morning when flowers began to close, while in $H$. undatus (clone A) and $H$. costaricensis, pollen germinability declined only the following evening, by which time the flowers had already closed. Pollen of $S$. megalanthus sampled when flowers started to open or $12 \mathrm{~h}$ later had very low germinability $(<4 \%)$. Changing the concentration of the medium components or using other germination methods, such as hanging-drop, standingdrop, and mass culture techniques (Calzoni et al., 1979), did not affect the germination of $S$. megalanthus pollen, which remained low (data not shown). Viability of fresh pollen was high, $90 \%$ to $94 \%$, in the Hylocereus spp. and about one-third of it in S. megalanthus (Fig. 6).

Effective pollination period. Pollination of $H$. polyrhizus and $H$. costaricensis with fresh pollen of $H$. undatus (clone A) led to high fruit set and heavy fruit (Table 5). Pollination was conducted during the period between the time 

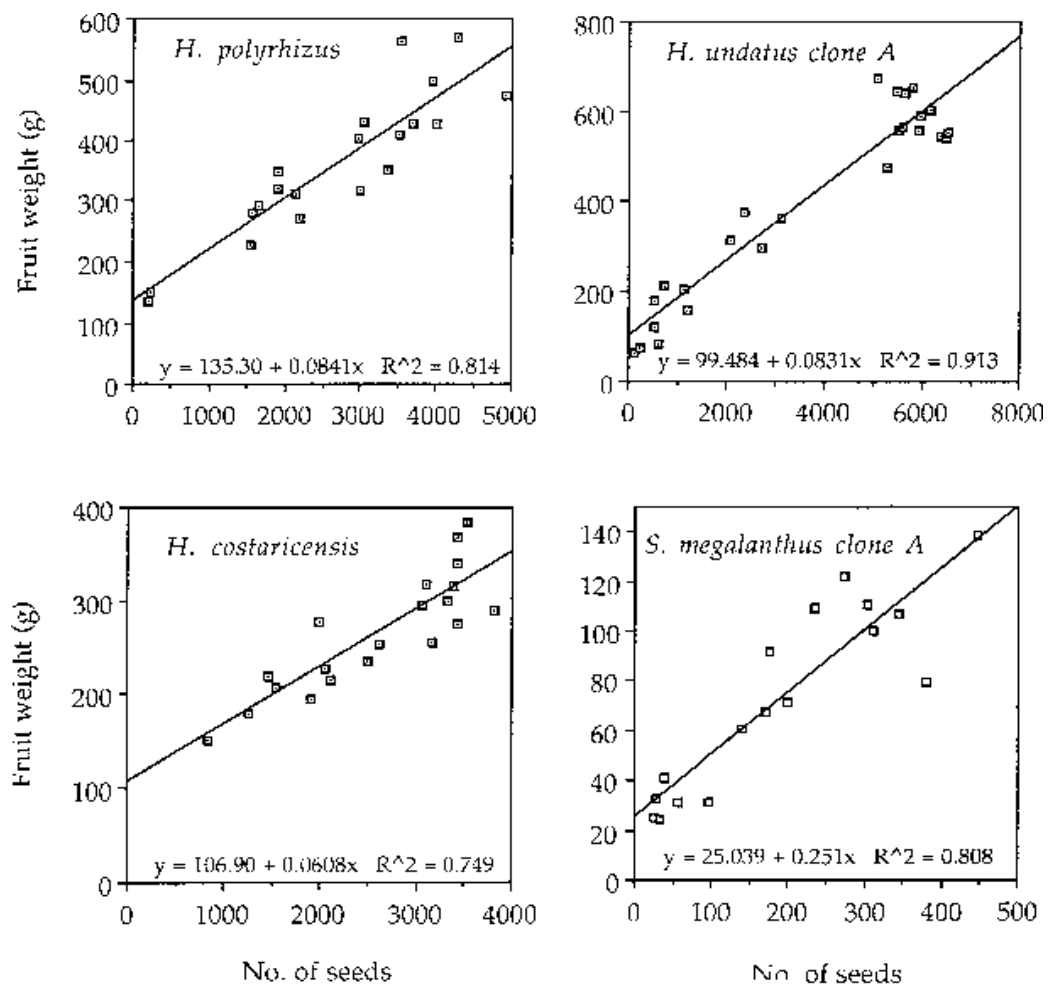

Fig. 4. Relationship between fruit weight and seed count in Hylocereus spp. and in Selenicereus megalanthus. Fruit included in the analysis were from open- and hand-pollination treatments. Calculations are based on measurements of 17 to 25 fruit for the various species $(P=0.01)$.

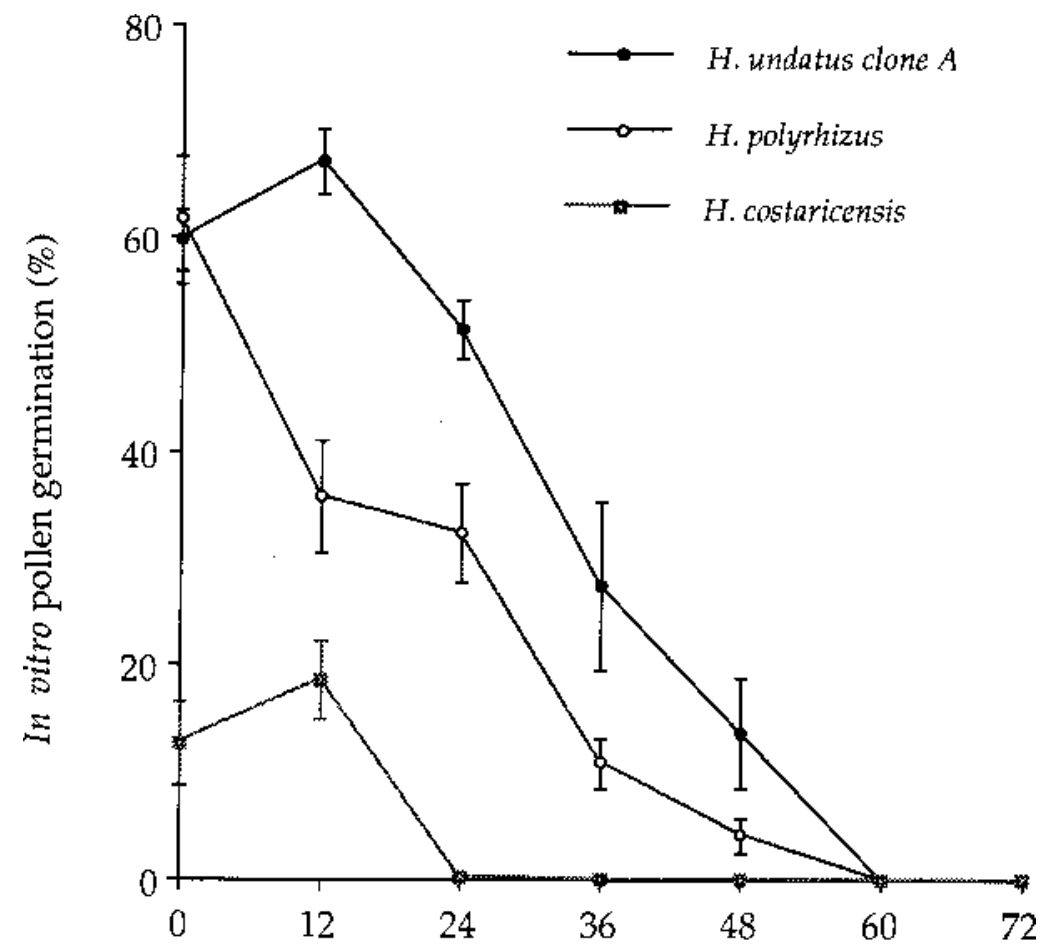

Time after flower opening (h)

Fig. 5. In vitro germination of pollen of Hylocereus undatus clone A, H. polyrhizus, and $H$. costaricensis sampled from flower opening over $60 \mathrm{~h}$. Values are the average of counts of 100 pollen grains from six randomly selected flowers.

of flower opening in the evening and the evening of the following day. Later pollination produced significantly lower fruit weights, and no fruit set when pollination was conducted 2 days after flower opening.

Effect of open pollination on fruit set and fruit weight. Fruit set with open pollination was higher in $S$. megalanthus $(80 \%)$ than in Hylocereus spp. (12.5\% to 50\%) (Table 6). Hand cross-pollination resulted in higher fruit set and heavier fruit than were achieved by open pollination in the Hylocereus spp. In $S$. megalanthus, fruit weight in open pollination was similar to fruit weight after hand pollination. Open-pollinated flowers were visited only by honeybees, indicating that pollen transfer was related to honeybee activity.

\section{Discussion}

Studies on the pollination requirements of orchard crops usually examine the compatibility between cultivars within species. In the case of the climbing cacti under discussion, some are not cultivated at all, and for the commercially cultivated species, no defined cultivars are available (Barbeau, 1990). Since preliminary studies had shown us that crosspollination between the investigated species was successful, the study set out to examine the possibility of using particular species as pollinators for other species. For the commercial species, $H$. undatus and $S$. megalanthus, the availability of clones differing in origin and in some morphological traits allowed us to extend the study within these species.

Two species, $H$. undatus and $S$. megalanthus, were self-fruitful. For both species, the involvement of pollen vectors was important for fruit production: $H$. undatus set fruit only when hand self-pollinated, and $S$. megalanthus, which set fruit by self-pollination without a pollen vector, produced heavier fruit when hand self-pollinated. The ability of flowers to set fruit without the involvement of a pollen vector was associated with flower morphology: upper anthers touched the stigma lobes in S. megalanthus during flower closing, but anthers were separated spatially from the stigma in the Hylocereus spp.

Studies of the breeding system lead to some practical conclusions with regard to the desired orchard design: a) S. megalanthus can be planted alone (one or two clones) because of the high fruit set obtained by self- and crosspollination between the clones. b) Fruit production in $H$. undatus would benefit from planting this species with pollinizers of two other Hylocereus spp., $H$. polyrhizus, and $H$. costaricensis, which induced both high fruit set and heavy fruit in $H$. undatus. The flowering period of the two proposed pollinizers was parallel to that of $H$. undatus. c) In the selfunfruitful species, $H$. polyrhizus and $H$. costaricensis, any of the Hylocereus spp. may be planted as pollinizers in relation to their influence on fruit set and fruit weight and synchronous flowering.

As is the case for other fruit crops producing abundant seeds, such as kiwifruit [Actinidia deliciosa (A. Chev.) C.F. Liang et R. Ferguson 


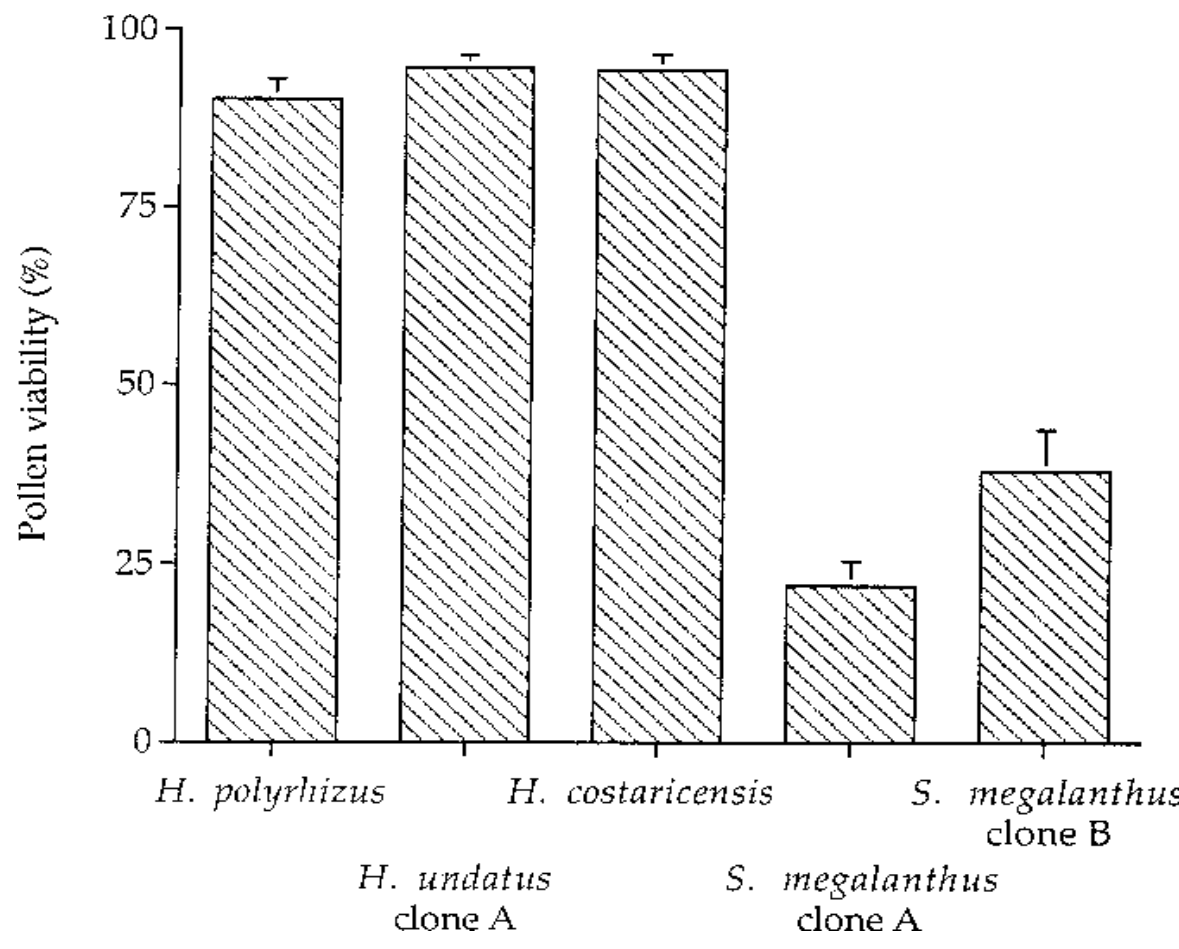

Fig 6. Pollen viability of Hylocereus spp. and Selenicereus megalanthus clones. Pollen viability was determined by a fluorochromatic assay. Pollen samples were taken shortly after flower opening. Values are the average of counts of 100 pollen grains from six randomly selected flowers.

var. deliciosa] (Hopping and Jerram, 1979) or feijoa (Feijoa sellowiana Berg.) (Patterson, 1990), fruit weight in the cacti was highly correlated with seed count. Thus, attention must be paid to obtain efficient pollination in the plantation. The maximum percentage of ovules that developed into seeds was $23 \%$ in $S$. megalanthus (clone A), whereas a maximum of $90 \%$ of the ovules set seed in $H$. undatus (clone A). The low seed set in S. megalanthus (clone A) can be related to the low viability and germinability of its pollen. Higher seed set and, therefore, higher fruit weight could probably be obtained by pollinating with highly viable pollen of other clones of S. megalanthus or other Selenicereus spp.

Although the flowers of both genera displayed the characteristics of those pollinated by night-active pollinators (Grant and Grant, 1979; Haber, 1983), the only pollen visitor to Hylocereus and Selenicereus was a day-active honeybee. The honeybee is a polytropic pollinator and forages on many nocturnal cactus flowers, including the saguaro [Carnegiea gigantea (Engelm.) Britt. \& Rose], the organ pipe cactus [Stenocereus thurberi (Engelm.) Britt. \& Rose] (Alcorn et al., 1962; McGregor et al., 1962; Schmidt and Buchmann, 1986), and the apple cactus [Cereus peruvianus (L.) Miller] (Weiss et al., 1993). The low rate of fruit set and the low fruit weight recorded for open pollination in the Hylocereus spp. indicates that the bees were not effective pollinators for these species under the conditions of our study. The bees visited the flowers only in the morning before flower closing. Since pollen germinability and female receptivity were high at this time, the low pollination effectivity has to be related to other factors, possibly

${ }^{y}$ Mean separation by Fisher's PLSD test, $P \leq 0.05$. the brevity of the visits and the lack of specific adaptation to the flower; for example, bees did not reach the nectar accumulated at the base of the flower tube. In S. megalanthus, fruit set and fruit weight with open pollination were similar to those obtained in hand pollination. This feature may be related to the fact that pollen transfer in open pollination is achieved by bee visits and by direct transfer of pollen to the stigma, which occurs via physical contact between anthers and stigma during flower closing.

Further studies will have to be made on improving the efficiency of the bees as pollinizers for the Hylocereus spp. with regard to the interaction between the flowers of the climbing cacti and bee behavior in the plantation. The problems associated with pollination by bees do not occur when pollination is carried out artificially. Hand pollination ensured high fruit set and heavy fruit when conducted during the entire period of anthesis. Hand pollination can thus be carried out conveniently during the morning hours, if economically feasible. Other potential pollinators of the climbing cacti exist in Israel; for example, the large carpenter bee (Xylocopa pubescens L.) potentially could be introduced successfully inside the shaded greenhouse.

The results of this study clarify various aspects of the reproductive biology of promising climbing cacti, including the flower phenology, the compatibility system, and the pollination type, which will enable the grower to define the agromanagement required for productive plantations. More studies concerned with clones are needed to determine if solid species plantations, consisting only of different clones of one species, may be established.

\section{Literature Cited}

Alcorn, S.M., S.E. MacGregor, and G. Olin. 1962. Pollination requirements of the organpipe cactus. Cactus Succulent J. (Amer.) 34:134-139.

Barbeau, G. 1990. La pitahaya rouge, un nouveau fruit exotique. Fruit 45:141-147.

Table 5. Effect of timing of pollination on percentage of fruit set and fruit weight in two Hylocereus spp. Hylocereus undatus clone A was the pollen source.

\begin{tabular}{lccc}
\hline \hline & $\begin{array}{c}\text { Time after } \\
\text { flower opening } \\
(\mathrm{h})\end{array}$ & $\begin{array}{c}\text { Fruit set } \\
(\%)\end{array}$ & $\begin{array}{c}\text { Fruit wt } \\
(\mathrm{g})\end{array}$ \\
\hline H. polyrhizus & 0 & 100 & $392 \mathrm{ab}^{\mathrm{y}}$ \\
& 12 & 100 & $396 \mathrm{a}$ \\
& 24 & 100 & $304 \mathrm{bc}$ \\
& 36 & 38 & $228 \mathrm{c}$ \\
H. costaricensis & 48 & 0 & --- \\
& 0 & 100 & $316 \mathrm{a}$ \\
& 12 & 100 & $369 \mathrm{a}$ \\
& 24 & 100 & $241 \mathrm{~b}$ \\
& 36 & 20 & $154 \mathrm{bc}$ \\
\hline
\end{tabular}

In each species 7 to 11 flowers were pollinated at a time.

Table 6. Effect of pollination type on fruit set and fruit weight in climbing cacti. For the Hylocereus spp., fruit set and fruit weight are the mean of 2 years of observation.

\begin{tabular}{llccc}
\hline \hline Species & $\begin{array}{c}\text { Pollination } \\
\text { type }\end{array}$ & No. flowers & $\begin{array}{c}\text { Fruit set } \\
(\% \text { of total })\end{array}$ & Fruit wt (g) \\
\hline H. polyrhizus & Hand cross & 37 & 100 & $599 \pm 25$ \\
& Open & 24 & 20.8 & $108 \pm 11$ \\
H. undatus & & & \\
clone A & Hand cross & 30 & 100 & $588 \pm 15$ \\
& Open & 44 & 43.2 & $120 \pm 13$ \\
H. costaricensis & Hand cross & 30 & 100 & $291 \pm 19$ \\
Selenicereus megalanthus & Open & 16 & 12.5 & $113 \pm 12$ \\
$\quad$ clones A and B & Hand cross & 15 & 100 & $116 \pm 4$ \\
& Open & 10 & 80 & $121 \pm 5$ \\
\hline
\end{tabular}


Britton, N.L. and J.N. Rose. 1963. The Cactaceae. vol. I and II. Dover Publications, New York.

Cacioppo, O. 1990. Pitaya: Una de las mejores frutas producida por Colombia. Informativo Agroeconomico Febrero:15-19.

Calzoni, G.L., A. Speranza, and N. Bagni. 1979. In vitro germination of apple pollen. Scientia Hort. 10:49-55.

Cullmann, W., E. Goetz, and G. Groener. 1987. The encyclopedia of cacti. Timber Press, Portland, Ore. p. 340.

Dennis, F.G., Jr. 1986. Apple, p. 1-44. In: S.P. Monselise (ed.). Handbook of fruit set and development. CRS Press, Boca Raton, Fla.

Donají Ortiz Hernandez, Y. 1993. Hylocereus spp: Plantas natives de potential ornamental y fruticola en Oaxaca. Investigación Hoy, Febrero:13-14.

Gibson, A.C. and P.S. Nobel. 1986. The cactus primer. Harvard Univ. Press, Cambridge, Mass.

Grant, V. and K.A. Grant. 1979. The pollination spectrum in the southwestern American cactus flora. Plant Syst. Evol. 133:29-37.
Haber, W.A. 1983. Hylocereus costaricensis (pitahaya silvestre, wild pitahaya), p. 252-253. In: D.H. Janzen (ed.). Costa Rican natural history. The Univ. of Chicago Press, Chicago.

Heslop-Harrison, J., Y. Heslop-Harrison, and K.R. Shivanna. 1984. The evaluation of pollen quality, and a further appraisal of the fluorochromatic (FCR) test procedure. Theor. Appl. Genet. 67:367-375.

Hopping, M.E. and E.M. Jerram. 1979. Pollination of kiwifruit (Actinidia chinensis Planch.): Stigma-style structure and pollen tube growth. N.Z. J. Bot. 17:233-240.

Kimnach, M. 1967. Hylocereus calcaratus. Cactus Succulent J. (Amer.) 39:102-105.

Kimnach, M. 1984. Hylocereus escuintlensis, a new species from Guatemala. Cactus Succulent J. (Amer.) 56:177-180.

McGregor, S.E., S.M. Alcorn, and G. Olin. 1962. Pollination and pollinating agents of the saguaro. Ecology 43:259-267.

Morton, J.F. 1987. Cactaceae, strawberry pear, p. 347-348. In: C.F. Dowling, Jr. (ed.). Fruit of warm climates. Morton J.F., Miami.

Patterson, K.J. 1990. Effects of pollination on fruit set, size, and quality of the feijoja (Acca sellowiana (Berg.) Burret). N.Z. J. Crop Hort. Sci. 18:127-131.

Raveh, E., J. Weiss, A. Nerd, and Y. Mizrahi. 1993. Pitayas (genus Hylocereus): A new fruit crop for the Negev Desert of Israel, p. 491495. In: J. Janick and J.E. Simon (eds.). New crops. Wiley, New York.

Schmidt, J.O. and S.L. Buchmann. 1986. Floral biology of the saguaro (Cereus giganteus) I. Pollen harvest by Apis mellifera. Oecologia (Berlin) 69:491-498.

Seaton, L. 1991. Pitaya: A classic case of novelty and lack of consumer awareness. Fresh Produce J. May: 10 .

Weiss, J., A. Nerd, and Y. Mizrahi. 1993. Development of Cereus peruvianus (apple cactus) as a new crop for the Negev Desert of Israel, p. 486-491. In: J. Janick and J.E. Simon (eds.). New crops. Wiley, New York. 